\title{
A Handbook of Parliamentary Procedure
}

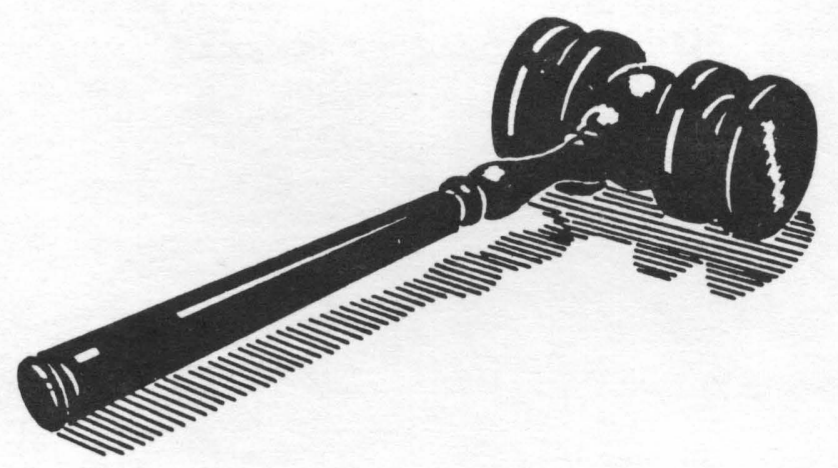


This publication is made possible, in part, by a grant from the W. K. Kellogg Foundation of Battle Creek, Michigan, to the Center for Volunteer Development at Virginia Tech and the Cooperative Extension Services of the following states:

Alabama

ALABAMA A\&M UNIVERSITY Normal, Alabama

(205) $851-5710$

AUBURN UNIVERSITY

Auburn, Alabama

(205) 844-3681

TUSKEGEE UNIVERSITY

Tuskegee, Alabama

(205) $727-8114$

\section{Georgia}

Fort Valley State College Fort Valley, Georgia

(912) 825-6268

UNIVERSITY OF GEORGIA

Athens, Georgia

(912) 382-3509

\section{TENNESSEE}

Tennessee State University Nashville, Tennessee

(615) 320-3650
Arkansas

UNIVERSITY OF ARKANSAS

Little Rock, Arkansas

(501) 373-2500

and

Pine Bluff, Arkansas

(501) 541-6500
MISSISSIPPI

ALCORN STATE UNIVERSITY Lorman, Mississippi (601) 877-6125
VIRGINIA

VIRGINIA POLYTECHNIC INSTITUTE AND STATE UNIVERSITY

Blacksburg, Virginia

(703) 231-7966

\section{No \\ Center for Volunteer Development}

Virginia Cooperative Extension programs, activities, and employment opportunities are available to all people regardless of race, color, religion, sex, age, national origin, handicap, or political affiliation. An equal opportunity/affirmative action employer.

Issued in furtherance of Cooperative Extension work. Virginia Polytechnic Institute and State University, Virginia State University, and the U.S. Department of Agriculture cooperating. James F. Johnson, Director, Virginia Cooperative Extension, Virginia Tech, Blacksburg; Clinton V. Turner, Administrator, 1890 Extension Program, Virginia State, Petersburg. 


\section{TABLE OF CONTENTS}

MEMBERSHIP PRIVILEGES and RESPONSIBILITIES $\ldots \ldots \ldots \ldots \ldots \ldots \ldots \ldots$

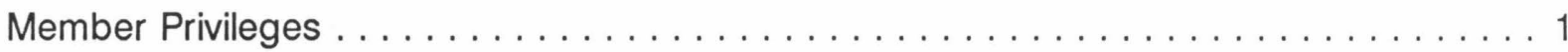

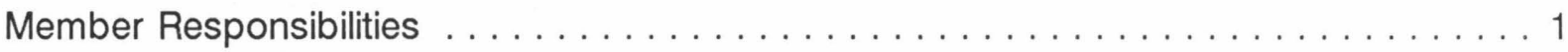

KEYS TO BEING A GOOD MEMBER $\ldots \ldots \ldots \ldots \ldots \ldots \ldots \ldots \ldots \ldots \ldots$

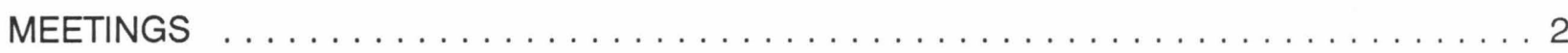

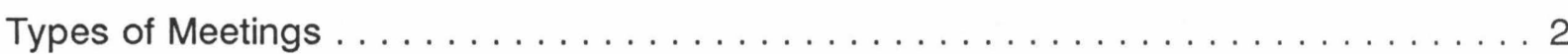

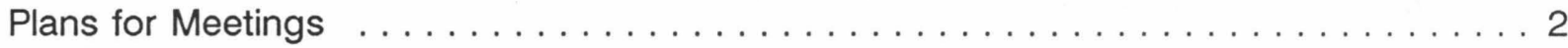

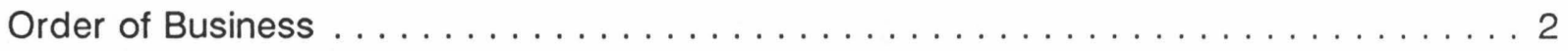

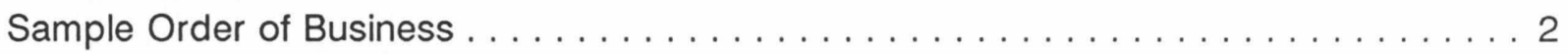

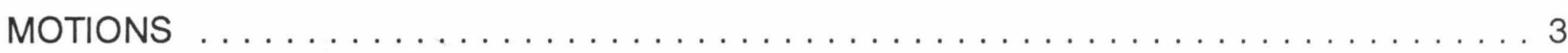

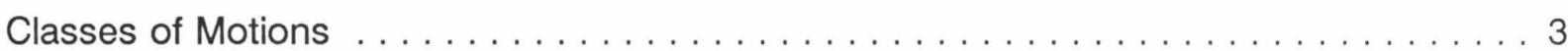

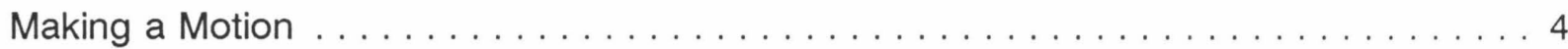

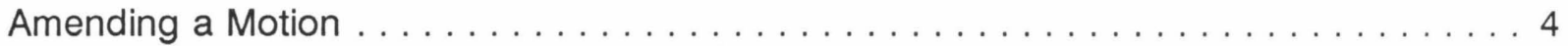

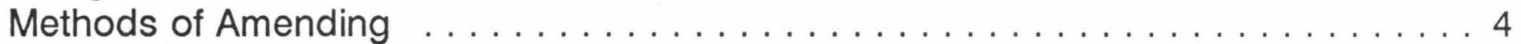

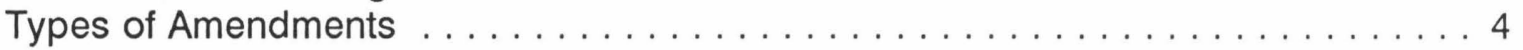

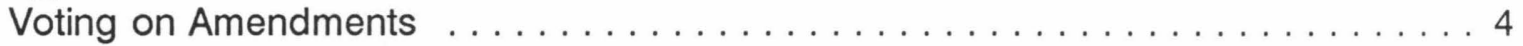

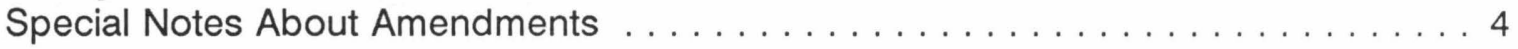

Resolution .................................. 5

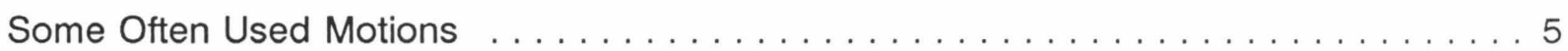

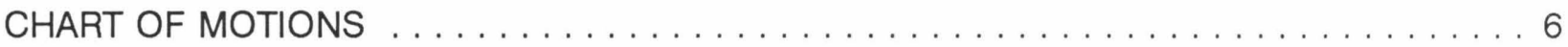

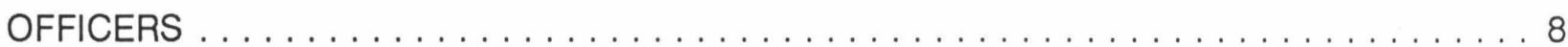

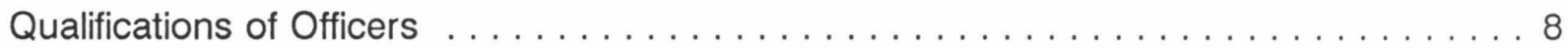

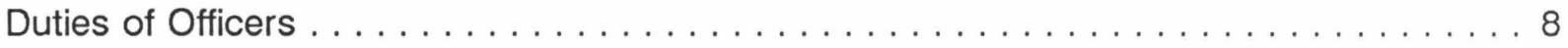

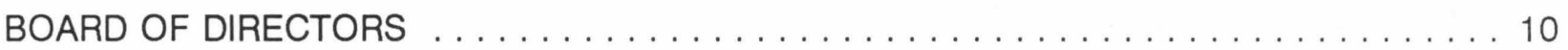

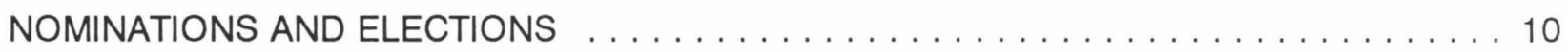

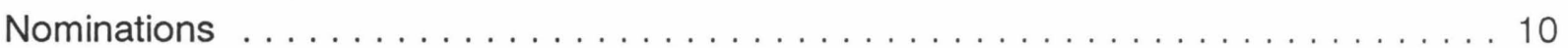

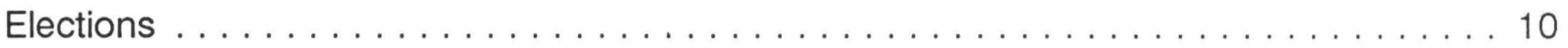

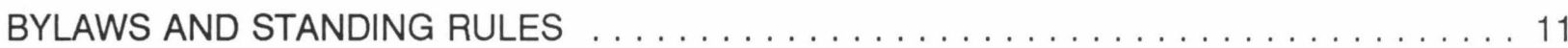

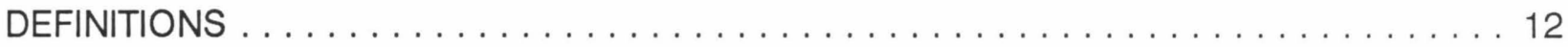

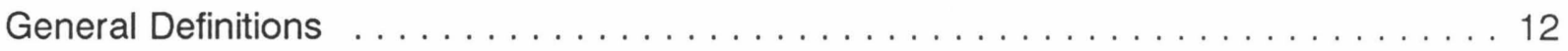

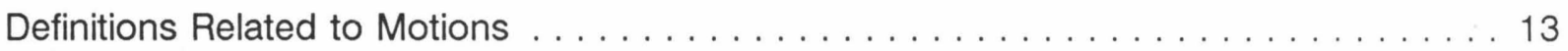

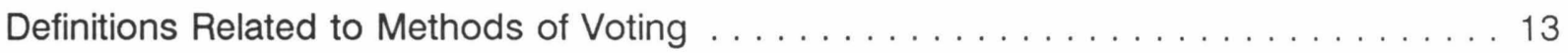

Definitions Related to Votes . . . . . . . . . . . . . . . . . . . . . . . . . 13

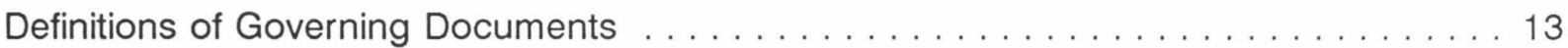




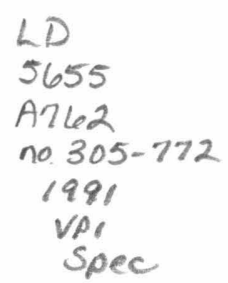

This publication is designed to help both experienced and inexperienced leaders and members conduct meetings of high quality and efficiency and provide guidance in organizational structure and functions. Knowledge of parliamentary rules is helpful to participants on every level. Members need to be aware of methods of good procedure, and leaders need to be knowledgeable in the use of proper techniques. The use of parliamentary procedure enables an organization to expeditiously and fairly accomplish the purpose for which it was organized.

Good parliamentary procedure insures justice to everyone, prescribes order, reflects kindness and courtesy and provides constructive use of limited time.

The text of this handbook is in harmony with the best authorities on parliamentary procedures (see references below). It is a streamlined guide adaptable to any size organization or assembly and provides simplified up-to-date practice and procedure. Parliamentary procedure is a special field with precise definitions and definite rules. It is difficult (dangerous) to re-word either definitions or rules and retain the same meaning. In some areas, Robert's Rules of Order states it best.

\section{ACKNOWLEDGEMENTS}

The authors are deeply indebted to the Virginia State Association of Parliamentarians and its Special Committee of Professional Registered Parliamentarians for valuable technical assistance voluntarily rendered in the production of this handbook.

Oscar M. Williams \& Delwyn A. Dyer

\section{REFERENCES}

Robert's Rules of Order Newly Revised, (1990 edition). Scott, Foresman \& Co. New York, NY.

Leonardy's Elementary Course in Parliamentary Procedure. National Association of Parliamentarians. Kansas City, MO.

Robert's Parliamentary Law, (1975). Irvington Publishers, Inc., New York, NY. 


\section{A HANDBOOK of}

\section{PARLIAMENTARY PROCEDURES}

\section{MEMBERSHIP PRIVLEGES and RESPONSIBILITIES}

No organization can exist without members. Qualifications for membership, which are determined by the organization, should be clearly stated in its governing rules (charter, constitution and/or bylaws). Some organizations define the different classes of membership, not all of which include full participation in the proceedings of the organization; however, the term "member" in this handbook refers to a person who has full participating rights.

When one joins an organization, he or she enters into a "contract" of membership with the organization. If a member feels that change is necessary, it should be brought about by working through proper channels and within the current rules.

Membership carries with it responsibilities as well as privileges, and where these are peculiar to the organization, they should be defined in its bylaws; however, it is neither necessary nor advisable to encumber bylaws with a list of privileges and responsibilities common to members of all organizations. Such a list of generally accepted privileges and responsibilities of membership includes, but is not limited to, the following:

\section{Member Privileges}

1. To attend meetings.

2. To make motions and enter into debate.

3. To vote.

4. To nominate and be nominated.

5. To insist on enforcement of the rules of the organization and of parliamentary law based on Robert's Rules of Order Newly Revised or other adopted authority.

6. To review official records of the organization, including the most recent governing document and the minutes of previous meetings.

\section{Member Responsibilities}

1. To promote the object and purpose of the organization.

2. To comply with and uphold the organization's governing rules.

3. To attend meetings regularly and punctually.

4. To give one's undivided attention to the business as well as the program of the meeting.

5. To abstain from acts or remarks outside the meetings that will in any way interfere with the work of the organization and/or its officers.

6. To hold office when requested.

7. To perform conscientiously any duty assigned and accepted in the organization.

\section{KEYS to BEING a GOOD MEMBER}

- Attends meetings regularly.

- Speaks up during the meeting, bringing out important points and contributing from one's own experiences.

- Learns to be brief, because brevity wins the good will of other members.

- Refrains from being technical, or more strict than is absolutely necessary for the good of the meeting.

- Considers ideas, not people.

- Serves willingly to the best of one's ability; thus gaining experience with each added duty.

- Confines oneself to the question before the assembly and avoids personalities.

- Practices correct parliamentary procedure.

(Adapted from material supplied by Virginia State Association of Parliamentarians) 


\section{MEETINGS}

\section{Types of Meetings}

All organizations conduct their affairs through meetings. Regardless of format, meetings are one of the following types.

1. Regular Meetings--those for which the time and place are usually prescribed in the bylaws or standing rules.

2. Special Meotings--those called for transaction of a special item of business. Procedure usually defined in bylaws.

3. Annual Meetings--those scheduled for hearing reports, electing officers, amending rules, and such other business as may need to come before members at the close of the organization year.

\section{Plans for Meetings}

An understanding of the meaning of the following terms is helpful to meeting planners.

Session: A meeting or series of connected meetings devoted to a single order of business.

Order of Business: The sequence of business to be conducted at a session of an assembly.

Agenda: An order of business, expressly adopted for a particular session, which assigns times and positions to specific items of business. (Used in a convention or meeting of an organization that convenes less than quarterly.)

Program: Includes business items, times for speakers, meals, and other non-business items (may include an agenda). Programs are usually used in conventions.

Call to Order: On time, after ascertaining the presence of a quorum, the presiding officer takes the chair, signals (raps gavel once) for quiet, and while standing says, "The meeting will come to order".

\section{Order of Business}

An Order of Business is essential to all meetings in which business of the organization is transacted. It helps the presiding officer and members to proceed in an orderly way, maintains continuity in the transaction of business and establishes priorities for items of business. Orders of Business should not be included in the bylaws since the bylaws may never be suspended.
Parliamentarians recommend that every group adopt a parliamentary authority as a guide. Robert's Rules of Order Newly Revised is one of the most widely accepted authorities in both deliberative and legislative assemblies.

\section{Sample Order of Business}

* Opening Ceremonies (in the order in which they should occur, if appropriate for your agenda)

1. Invocation (prayer)

2. Singing or playing of National Anthem

3. Pledge of Allegiance to the Flag of the United States of America

4. Ritual (for fraternal organizations)

* Roll Call (when organization requires-generally, in small organizations a sign-in sheet may be sufficient.)

1. Minutes. "The secretary will read the minutes." Secretary stands to read, but does not address chair at this time. If there is more than one set, read earliest ones first. Approval and corrections are usually made by unanimous consent. ("Are there corrections? [pause] If not, the minutes stand approved as read.") If a committee is appointed to approve minutes, its chair or designated member should also report at this time.

\section{Adoption of Agenda}

3. Reports of Officers. At annual meeting, all officers report. At other meetings, chair calls on those who have reports. Report in the order listed in bylaws. Officers do not move adoption of action proposed by their own report. Corresponding Secretary reads correspondence not requiring action. Recording Secretary reads other correspondence under "New Business".

4. Report of Board. The report to which a majority of the Board agrees. It may contain recommendations for action. This report is usually read by the Recording Secretary.

5. Reports of Standing Committees. Called for in the same order as listed in the bylaws (should be alphabetical). Recommendations arising from report are usually handled immediately. 
6. Reports of Special Committees. Called for in order of appointment. Only those prepared or instructed to report are called upon.

7. Special Orders. Matters which bylaws require to be considered at a particular meeting-such as nominations and elections. Also, motions postponed by a $2 / 3$ vote and made a special order for this meeting are considered here.

8. Unfinished Business and General Orders. Should NOT be announced unless minutes show there is business to come under this heading. If previous notice was given, bylaws amendments aro considered here. Motions postponed until this meeting by a majority vote are considered here.

9. Now Business. Correspondence that requires action is considered first. After this, consideration is given to items members have brought or reported for discussion.

* Good of the Order. Refers to the new business or information thought to be good for the general welfare of the organization (not often used).

* Announcements. Should be made by the presiding officer.

* Program. Programs are usually presented just prior to adjournment. The time of the program may be changed by the assembly. This is usually done by unanimous consent.

* Adjournment Done by either unanimous consent or formal motion. The meeting is not adjourned until the chair declares, "The meeting is adjourned" (may rap gavel once).

NOTE: The headings marked with an * are optional. If used, they appear in the order listed.

(Adapted by Oscar M. Williams from materials prepared by Helen L. Anderson, PRP, from information contained in the 1990 Edition of Robert's Rules of Order Newly Revised.)

\section{MOTIONS}

A motion is a formal proposal which brings a subject to a group for its consideration and action. Motions are not all the same. They fall within certain classes and some take priority over others. Only members who have a right to vote may make a motion, speak in debate on it, and vote.

\section{Classes of Motions}

1. Main Motions. A main motion introduces a question or business for consideration when no other business is pending. Only one main motion may be considered at a time, and no other main motion can be introduced until the first one is disposed of in some manner. It is the lowest rank of all motions.

2. Subsidiary Motions. Subsidiary motions help the assembly to treat or dispose of a main motion. Since they relate to the question before the house, a subsidiary motion may be proposed when a main motion is still before the assembly. The vote on the subsidiary motion is taken before the main motion is acted upon. Subsidiary motions have definite rank.

3. Privileged Motions. Privileged motions do not relate to pending business, but deal with special matters of immediate and overriding importance. Privileged motions may interrupt debate before the assembly. They have definite rank. (See chart of motions, p. 6.)

4. Incidental Motions. Incidental motions are those that help facilitate a pending motion or other business at hand; such as, suspending the rules or closing nominations. Incidental motions have no rank. (See chart of motions, p. 6.)

5. Motions That Bring a Question Again Before the Assembly. These motions bring a question back that has already been considered before the assembly, as in the case of the motions to rescind or take from the table. These motions have no rank. (See chart of motions, p. 6.) 


\section{Making a Motion}

To make a motion, follow these procedures:

1. Member rises and addresses the Chair, "Mr./Madam President or Chairman."

2. Chair recognizes the member.

3. Member: "I move that ... . (states motion)."

4. Second to motion. (not necessary to stand) "I second the motion." If the motion comes as a recommendation from two or more members, the motion does not need a second.

5. Chair states motion. "It has been moved by (name) and seconded that ..."

6. Discussion. If the motion is debatable, every member has the right to debate; the Chair refrains from debate while presiding. The Chair carefully determines the order in which members are recognized to speak, giving first opportunity to the proposer of the motion. Care should be taken to assure that discussion is related to question.

7. The Chair says, "If there is no further discussion, the motion is ... (restate motion)."

8. Vote. The Chair says, "All those in favor of . . (the motion stated) . . . say 'aye.' Those opposed say "no.'"

9. Result of the vote is stated by the Chair. "The motion is carried" or "the motion is lost."

\section{Amending a Motion}

To amend a motion is to alter or modify the wording of a pending motion (a motion that has already been made) before it is acted upon.

METHODS OF AMENDING. Motions may be amended by three methods:

1. Inserting. Words may be inserted at any place, or if at the end of the motion, words may be added. Paragraphs may be inserted or added in the same fashion.

2. Striking out. Words and paragraphs may be struck out in the same fashion as they may be inserted.

3. Substituting. This is a combination of inserting and striking out.

An amendment must be germane to the main motion.

\section{TYPES OF AMENDMENTS.}

1. Primary. An amendment that is germane to the main motion.

2. Secondary. An amendment that is germane to the primary amendment only.

No amendment other than primary and secondary ones is in order, and only one of each may be made at one time. It is possible to have a motion, an amendment to the motion, and an amendment to the amendment before the assembly at one time.

\section{VOTING ON AMENDMENTS.}

1. Discuss and vote on secondary amendment.

2. Discuss and vote on primary amendment as amended (if amendment carried).

3. Discuss and vote on main motion as amended (if amendments carried).

\section{Special Notes ABout Amendments.}

1. There may be only one primary and one secondary amendment pending to the same motion at the same time.

2. The primary amendment must be germane to the motion, and the secondary amendment must be germane to the primary amendment.

3. A hostile amendment is in order if it is germane. (An amendment may change a motion of commendation to one of censure. The amendment would be germane as in both cases it expresses the opinion of the assembly.)

4. The order of proposing these motions is the opposite of the order of disposing of these motions.

Propose: main motion, primary amendment, then secondary amendment.

Dispose: (vote or decide on) secondary amendment, primary amendment (as amended, if it was), main motion (as amended, if it was).

5. The subsidiary motion to amend may be applied to main motions and to certain other motions. If applied to a main motion, it takes precedence over the motion it proposes to amend.

6. Amend requires a majority vote, even if the motion to be amended requires a 2/3 vote.

7. A substituted paragraph or motion may be amended only by adding something that does not modify the existing content. 


\section{Resolutions}

A resolution is a long main motion set in writing. That is, a resolution is usually of such length or importance that it should be written. It may or may not have a preamble setting forth the reasons for it. (For proper form, see Robert's Rules of Order Newly Revised, 1990, pp. 105-107.)

The object of a resolution is to introduce business. The following factors apply:

- Requires recognition

- Requires a second (unless introduced by a committee of more than one person)

- Is debatable

- Is amendable

- Yields to all privileged, incidental, and subsidiary motions

- Requires a majority vote for adoption

- May be reconsidered

Some important points: As a main motion, a resolution is the lowest ranking of all motions, and when pending, any other motion might be in order. As with other main motions, resolutions may be made only when no other motion is pending--when the floor is clear. (The chair may require that all main motions, amendments, or instructions to a committee be in writing.) If lost, a main motion may not be made again in the same session.

\section{Some Often Used Motions}

Main Motion--a motion to bring a matter before the assembly for discussion and action.

Amendments--proposals intended to modify or change a motion. (See "Amending a Motion.")

Postpone Indefinitely--to reject a motion or pending question without taking a direct vote. The effect is to "kill" the main motion.

Refer to a Committeo--a motion to send to a group for greater consideration or study of a matter.

Postpone to a Definite Time--to delay action on a proposed question to a specific time.

Limit or Extend Debate--to limit by decreasing the allotted time or to extend by increasing the allotted time. (See chart of motions, p. 6.)
Call for the Previous Question--a motion to determine whether the assembly will cut off debate and further amendments and vote at once on the pending question (requires a $2 / 3$ vote).

Lay on the Table--a motion which enables the assembly to put aside temporarily a pending question, in order to consider an urgent matter; can be brought back by a motion to take from the table. (Not intended as a killing motion.)

Call for Orders of the Day--a request to conform to order of business.

Questions of Privilege (Personal and General)--a motion requesting privilege for an individual or the assembly (e.g., too hot in room or too noisy).

Recess--to provide for a short intermission in meeting.

Adjourn--to close a meeting.

Fix Time \& Place to Which to Adjourn--to provide for another meeting (called "adjourned meeting") to continue business which was not completed in present meeting.

Point of Order--to request enforcement of the rules of order.

Appeal from the Decision of the Chair--to question a decision of the Chair; an effort to reverse the decision of the Chair whenever the Chair has "ruled" on question of parliamentary law.

Objection to Consideration--to suppress and prevent discussion of an undesirable or sensitive question (must be raised before debate begins).

Withdraw--to remove a matter for consideration without a vote upon it. (May be made by the mover or by permission of assembly.)

Take from the Table--to take up a matter which has been laid on the table.

Reconsider--to bring back a matter previously decided upon (or acted upon). Motion to reconsider must be made by voter on prevailing site and must be made on the same day or in same session.

Rescind--to repeal or annul action previously taken. Requires majority vote with previous notice; 2/3 vote, without notice.

Ratify--to make legal any action taken in an emergency. 


\begin{tabular}{||l|}
\hline \\
\hline \\
\hline PRIMLEGED MOTIONS \\
\hline To fix the time to which to adjourn \\
\hline To adjourn \\
\hline To recess \\
\hline To rise to a question of privilege \\
\hline To call for the order of the day \\
\hline SUBSIDIARY MOTIONS \\
\hline To lay on the table \\
\hline To call for the previous question \\
\hline To limit or extend limit of debate \\
\hline To postpone to a definite time \\
\hline To refer to a committee \\
\hline To amend \\
\hline To postpone indefinitely \\
\hline INCIDENTAL MOTONS (have no rank or precedence) \\
\hline To suspend the rules \\
\hline To withdraw a motion \\
\hline To request permission to read papers \\
\hline To object to consideration \\
\hline To rise to a point of order \\
\hline To rise to a parliamentary inquiry \\
\hline To appeal from the decision of the Chair \\
\hline To call for a division of the house \\
\hline To call for a division of the question \\
\hline $\begin{array}{l}\text { MOTIONS THAT AGAIN BRING A QUESTION BEFORE THE HOUSE } \\
\text { (have no rank or precedence) }\end{array}$ \\
\hline To reconsider (see definition, Some Often Used Motions, p. 5) \\
\hline To rescind \\
\hline To take from table \\
\hline MAIN MOTIONS \\
\hline
\end{tabular}




\begin{tabular}{|c|c|c|c|}
\hline \multicolumn{4}{|c|}{ CHART OF MOTIONS (Continued) } \\
\hline $\begin{array}{c}\text { In order when another } \\
\text { has the floor }\end{array}$ & $\begin{array}{l}\text { Requires } \\
\text { a Second }\end{array}$ & Debatable & Vote Required \\
\hline No & Yes & No & Majority \\
\hline No & Yes & No & Majority \\
\hline No & Yes & No & Majority \\
\hline Yes & No & No & Chair rules \\
\hline Yes & No & No & None \\
\hline No & Yes & No & Majority \\
\hline No & Yes & No & Two-thirds \\
\hline No & Yes & No & Two-thirds \\
\hline No & Yes & Yes & Majority \\
\hline No & Yes & Yes & Majority \\
\hline No & Yes & Yes & Majority \\
\hline No & Yes & Yes & Majority \\
\hline No & Yes & No & Two-thirds \\
\hline Yes & No & No & Majority \\
\hline Yes & Yes & No & Majority \\
\hline Yes & No & No & Two-thirds (opposed) \\
\hline Yes & No & No & Chair rules \\
\hline Yes & No & No & Chair responds \\
\hline Yes & Yes & $\begin{array}{l}\text { Unless relates to priority } \\
\text { of business or decorum }\end{array}$ & Majority (in negative) \\
\hline Yes & No & No & None \\
\hline No & Yes & No & Majority \\
\hline No & Yes & Yes & Majority \\
\hline No & Yes & Yes & $\begin{array}{l}\text { Majority, with previous } \\
\text { notice; } 2 / 3 \text {, otherwise }\end{array}$ \\
\hline No & Yes & No & Majority \\
\hline No & Yes & Yes & Majority \\
\hline
\end{tabular}




\section{OFFICERS}

Good leadership and informed membership are directly related to the officers' knowledge and skillful use of parliamentary procedure. The usage-extent and the diversity--depends on the particular organization. Since the quality and effectiveness of an organized group are often determined by the proficiency of its leaders, choices of officers and other leaders must be made on the basis of the best qualifications for appropriate positions. Officers should be familiar with functions of their office and duties as prescribed by the organization's bylaws.

The term PRESIDENT or CHAIRMAN is a title given to the presiding officer, unless a special title is chosen by the organization. The officers in line to serve in the absence of the PRESIDENT are VICE-PRESIDENTS or VICE-CHAIRMEN. The SECRETARY is the recording officer and fills other secretarial duties if there is no CORRESPONDING SECRETARY. The TREASURER is the custodian of funds.

There may be additional officers specified in the bylaws, (e.g., Directors, Librarian, Historian and Chaplain) with assigned special duties. The specific duties of these and other officers are spelled out in the parliamentary authority adopted by the association.

The PARLIAMENTARIAN is a consultant to the PRESIDENT or other members of the organization and should be appointed by the PRESIDENT.

\section{Qualifications of Officers}

President Should be a member in good standing and know the structure and purpose of the organization; have the ability to get along well with people; be able to preside with dignity; have a sense of humor.

VicePresident

Recording Secretary
Should be cordial and tactful and understand good principles of letter writing.

Treasurer Should have an understanding of good business procedure, capacity for handling money, some bookkeeping skills, and unquestioned honesty.

Qualifications of the other officers depend on the purpose for which they exist, as defined by the organization and its rules.

\section{Duties of Officers}

The general and specific duties of officers are included in the bylaws and standing rules of the particular organization. The following list includes duties generally considered important for good performance.

\section{PRESIDENT:}

1. Prepare a detailed order of business or agenda for each meeting.

2. Open meetings on time as designated.

3. Conduct the meeting but not dominate it; be firm, but courteous.

4. Know the rules of correct procedure and use them skillfully.

5. Exact obedience to bylaws and other rules and policies.

6. Conduct business in a manner that insures the right of every member.

7. Meet the demands of the office unselfishly.

8. If given the authority, selects chairmen, committees, and appointed officers for particular assignments.

9. Leave the chair to debate.

10. Vote as other members in ballot vote (may vote to make or break tie or whenever vote will affect the result or outcome of the motion). Can vote in counted, rising, or roll call votes.

11. Observe and supervise the basic program of work of the local and the parent organizations.

12. Where bylaws designate, serve as ex-officio member of committees.

13. Sign all necessary orders, reports or financial transactions as defined in the rules of the organization. 
14. Acquire and use all tools necessary to the conduct of the office (bylaws and other rules of the group and parent organization; a copy of the parliamentary authority specified in the bylaws; appropriate handbooks, year books, publications; list of officers, chairmen and members).

\section{VICE-PRESIDENT:}

1. Preside in the absence of the President.

2. Assume such other positions of responsibility as may be designated in the bylaws or otherwise prescribed.

3. If the bylaws so indicate, fill a vacancy in the office of President. Vice-Presidents, where there may be more than one, assume duties in the order of their office, (1st VicePresident, 2nd Vice-President, etc.)

\section{Secretary:}

1. Keep a precise permanent record of the proceedings called "minutes."

2. Keep a file of reports.

3. Prepare a list of unfinished business for the President.

4. Have for ready reference in meetings: minutes, bylaws and policy references, roll of members, other pertinent lists.

5. Take accurate notes of proceedings and transcribe them into permanent form immediately following the meeting. Request that complicated motions be provided in writing, signed by the maker of the motion.

6. Write minutes in brief, carefully-worded sentences.

7. Sign minutes with the name used in the membership roster. (Not "respectfully submitted"). When approved or corrected, initial or sign with date of approval. Write corrections in the margins.

8. Send a copy of minutes to the President within a reasonable time.

9. Read correspondence if there is no Corresponding Secretary; read reports of absentee members.

10. Present recommendations of the Board or Executive Committee. The Secretary may make motions, debate, and vote.

11. Sign, along with other officers, official papers and documents as prescribed.
12. Call a meeting to order in the absence of the presiding officers and preside over the election of a temporary Chairman.

\section{TREASURER:}

1. Be custodian of all funds.

2. Receive funds systematically and according to the rules.

3. Deposit all monies in such financial institutions as may be approved by the organization or its Board.

4. Disburse funds as designated and keep a schedule of payment obligations.

5. Expend funds on proper authority only.

6. Keep an accurate account and make such reports as may be desirable. Be prepared to have books audited and deliver records to successor on time.

7. Include in the report the balance at the beginning of the period, receipts, disbursements and balance on hand at close of period. The Treasurer's report is never adopted; it is referred for audit or placed on file.

8. Provide copies of the report to the President and the Secretary.

9. Where large amounts of money are involved, the Treasurer should be bonded for protection of the officer and the security of the organization.

\section{PARLIAMENTARIAN:}

1. Have a thorough knowledge of the parliamentary authority specified by the organization's bylaws and know the correct parliamentary procedure for conducting meetings and interpreting the rules of the organization.

2. Serve as an advisor to the President and other officers or members on matters related to the organization.

3. Give opinion or advice, not a "ruling" since the Chair rules.

4. Serve as a consultant to committees on rules, bylaws, elections, resolutions.

\section{OTHER OfFICERS:}

Duties of other officers should be carefully described in bylaws or rules according to the needs of the organization and its parent body. 


\section{BOARD of DIRECTORS}

Many organizations have a board to take care of the essential business between meetings. It may be called Board of Directors, Executive Board, Board of Managers or Board of Trustees. The bylaws should state the composition of the board; that is, who shall serve as members, and the duties and authority of the board.

There may also be an Executive Committee in large organizations. It is usually composed of the elected officers who act in emergencies between meetings of the Board or the membership. It is expedient in some instances to have this body as the only subordinate group with the duties and authority usually designated for a board.

\section{NOMINATIONS and ELECTIONS}

\section{Nominations}

A nomination is the presentation of the name of a person to the assembly as a nominee for an office to be filled.

Most organizations have detailed provisions for nominating and electing officers in the bylaws or other governing rules. Such details usually include the method of nominations, time of nominations, time and method of election.

Listed below are the most frequently used methods:

\section{Nominations from the Floor.}

a. In order, when the presiding officer calls for them.

b. Require no second.

c. The presiding officer repeats the names of the nominees and the secretary records them.

d. When the presiding officer is sure that every opportunity has been given for nominations, the presiding officer may declare the nominations closed. It is in order for any member to move to close nominations; the motion requires a $2 / 3$ vote. Nominations may be reopened by a motion and a majority vote.

\section{Nominations by a Nominating Committee}

a. The nominating committee shall be elected by the organization according to the organization's bylaws, policies, rules, and parliamentary authority.

b. The nominating committee shall submit to the organization, at the prescribed time, the names of nominees proposed for office (copies to presiding officer and Secretary).

c. Following the report of the nominating committee, the presiding officer shall call for nominations from the floor. When no further nominations are presented, the presiding officer may declare the nominations closed or entertain a motion to close nominations.

d. The report of the nominating committee is never adopted. (Voting is the act of adoption.)

e. The membership of the organization may be informed of the names of proposed nominees before the meeting at which the committee submits its report. This should be written into the bylaws or standing rules if the procedure is acceptable.

\section{Elections}

Being nominated to office does not put a person in office. Nominees must be elected. To be elected to office involves member voting. The usual methods of voting, following the closing of nominations, are as follows:

1. Voice Vote: Election may be by voice vote unless a ballot vote is required.

a. Nominees are voted on in the order in which they are nominated.

b. Tellers may be appointed to assist with the count of votes and report to presiding officer.

c. The presiding officer officially announces the result and declares the election.

\section{Ballot Vote:}

a. Where a ballot vote on nominees is required or expedient, it is important to make the necessary preparation for ballots, ballot boxes, time allotment, and space as needed. 
b. Tellers to count the ballots should be carefully selected and instructed on correct procedure. Common sense and parliamentary authority must govern the validity of ballots.

c. Tellers report the result of the election at the designated time and give copies of the report to the presiding officer and the Secretary.

d. The presiding officer repeats the results and declares the election.

Officers assume their duties at the time designated by the organization. Usually the time is stated in the bylaws, and they generally specify that the newly-elected officers will take office at the close of the meeting at which they are elected or following an installation at some future time. If no rule exists in practice or policy, the officers assume their duties upon election.

Organizations that have a widely distributed membership and find it difficult to assemble members for elections may opt to hold elections by mail or permit proxy voting. Both of these methods are complicated and require governing rules.

\section{BYLAWS and STANDING RULES}

Bylaws. Simply defined, bylaws are "laws by which the organization has agreed to go by." (Williams) It is necessary that every permanent organization have rules in order to define the organization, to provide for efficient and equitable transaction of its business, and to protect its membership. These rules are generally in the form of bylaws, which deal with basic rules of the organization itself (name, purpose, etc.) and standing rules which deal with the administration of the organization. The recommended practice is to combine basic rules in a single instrument called "bylaws."

An organization which is incorporated, to meet legal requirements, has Articles of Incorporation, with bylaws and standing rules. Otherwise, bylaws and standing rules are the recommended form for rules of an organization.

There should be a committee to prepare proposed bylaws. (NOTE: If a qualified Parliamentarian is available, the assistance of one may be helpful in developing the proposed bylaws.) When completed, copies of the proposed bylaws should be given to every member in advance (at least one to two weeks) of the meeting at which they are to be considered and acted upon.

At the meeting at which the proposed bylaws are to be considered, a motion is made to adopt the proposed bylaws (usually made by the committee chairman or a member of the bylaws committee). The bylaws are read one Article at a time and discussed and amended before the membership proceeds to the next Article. After all Articles have been discussed, it is good procedure for the presiding officer to ask if there are any further amendments to any of the Articles discussed prior to the vote on the motion to adopt the bylaws. (NOTE: Bylaws become effective immediately upon their adoption unless otherwise stated.)

The following outline includes Articles that are usually found in bylaws, and the usual order in which they are found. Bylaws should be kept as simple and unrestrictive as possible, including only those rules necessary to facilitate the work of the organization. A suggested outline follows:

\section{ARTICLE I. Name}

The exact and properly-punctuated name should be used.

\section{ARTICLE II. Object}

A brief general statement of purpose.

\section{ARTICLE III. Membership}

This Article usually will have several sections dealing with membership qualifications, classifications (if any), acceptance and resignation procedures. Unless members' financial obligations are complicated, this Article should also include a section on required fees and dues and procedures for payment and notification of members, if they are delinquent.

\section{ARTICLE IV. Officers}

This Article will include sections naming officers, qualifications for office, terms of office, duties, procedures for election or appointment and for filling vacancies. 


\section{ARTICLE V. \\ Meoting}

This Article will include sections on regular meetings (hour or time is usually specified in the Standing Rules), annual meetings, and special meetings. It also includes a section establishing quorums for meetings.

\section{ARTICLE V. Governing Board (Executive Board, Board of Directors, etc.)}

This Article includes sections to establish composition of the Board, to specify powers delegated to the Board, and to set meeting and quorum requirements of the Board.

\section{ARTICLE VI. Committees}

This Article specifies necessary standing committees and duties of each. It should also include a section on special committees, how they shall be created and how committee members are appointed.

\section{ARTICLE VIII. Finance (if necessary)}

\section{ARTICLE IX Dissolution}

This Article (if necessary) pertains to IRS 501 (c)(3) tax free, charitable organizations.

\section{ARTICLE X. Parliamentary Authority}

This Article should contain a statement such as, "The rules contained in the current edition of Robert's Rules of Order Newly Revised shall govern this organization in all cases in which they are applicable and in which they are not inconsistent with these bylaws and any special rules this organization may adopt."

\section{ARTICLE X]. Amendments}

This Article will include requirements for amending bylaws. The accepted form is: Bylaws may be amended at any meeting, provided that the amendments have been submitted (preferably in writing) to the membership within a specified number of days prior to action on these amendments.
Standing Rules. Standing Rules deal primarily with administration of an organization. They are not necessarily proposed at the time of the adoption of the bylaws, rather they are presented and adopted as a need arises in the organization. Standing Rules are adopted by majority vote and may be suspended by majority vote. They can be amended or repealed by $2 / 3$ vote without previous notice, or by majority vote if previous notice is given.

\section{DEFINITIONS}

\section{General Definitions}

Adopt--to accept or approve a report or statement.

Adjourn--to close a meeting officially.

Agenda--a detailed listing of the items to be discussed at the business meeting.

Approve--to adopt, accept, agree to, or ratify.

Chair--the presiding officer; the president; the chairman.

Debate-discussion.

Ex officio--"by virtue of office." Full privilege of other members. Ex-officio officers should be designated in the bylaws.

Unanimous Consent--informal agreement without the formality of a motion; no one dissenting.

Germane-closely related; of the same subject matter.

Order of Business--a sequence of business to be taken up at a session of an assembly; a schedule of business to be considered at a meeting.

Pro Tem--for the time being; (from the Latin "pro tempore").

Quorum--the number of members, as stated in bylaws, that must be presented for a legal transaction of business. If not stated in bylaws, it is a majority of the membership. (The quorum should be the specific number of members who would attend the meeting if, for example, the meeting were held during bad weather.) 
Rank--relationship to the order of precedence of motions.

Recess--an intermission within a meeting approved by the members.

\section{Definitions Related to Motions}

Amend--modify or change.

Immediately Pending Question--the last question stated by the chair.

Motion--a formal proposal that certain action be taken; the question.

Original Main Motion--a motion which introduces a new subject.

Pending Question--a motion that has been stated by the chair and is under consideration.

Resolution--a formal, usually long, written motion. It may have a preamble setting forth the reasons it is introduced.

\section{Definitions Related to Methods of Voting}

Ballot Vote--a written vote; secrecy, the main objective.

Mail Vote--method to be provided in bylaws.

Proxy Vote--a vote cast by another on authority given by member; only valid if provided in bylaws.

Roll Call-voice vote by calling roll of members.

Rising Vote (or show of hands)--members stand or raise hands to indicate vote.

Unanimous Vote-no one dissenting.

Voice Vote--Response of "aye" or "no" by members to indicate vote.

\section{Definitions Related to Votes}

Call for a Division--a rising vote to determine the vote. Any one member has the right to request that a voice vote be retaken as a rising vote. Only the assembly may demand or order a counted vote.
Majority Vote-at least one more than half of the votes cast by persons entitled to vote.

Plurality Vote--the highest number of votes when there are three or more choices. If for election, must be provided for in bylaws.

Tie Vote--the same number of votes on each side.

Two-Thirds Vote--2/3 of the votes cast by persons entitled to vote.

\section{Definitions of Governing Documents (Laws and Rules)}

Articles of Incorporation--rules contained in a "corporate charter" issued by a state, setting forth legal agreements with the organization for the protection of the name, property and membership liability.

Bylaws--a document adopted by an organization which contains the basic rules for governing that organization. Parliamentarians now recommend that "constitution" and "bylaws" be combined into a single instrument called "bylaws."

Charter--a document issued by a parent organization granting permission to a local group to operate as an affiliate.

Rules of Order--written rules of procedure for business meetings.

Standing Rules--rules which deal with the details of the administration of an organization, are temporary or semi-permanent in nature, and may be adopted or changed without previous notice. 


